\title{
Combining GIS and Analytical Hierarchy Process for Landfill Siting, Study Area: Paveh County in Iran
}

\author{
Mahya Rostampoor*, Mitra Zamani, Amir Asadi Vaighan \\ Department of civil engineering, Faculty of Engineering, University of Urmia, Urmia, Iran (mahyarostampoor@gmail.com, \\ mitrazamani94@gmail.com,a.asadi@urmia.ac.ir)
}

\begin{abstract}
Landfill siting is a complex and challenging operation. It is one of the fundamental problems in waste management, where it is necessary to consider different conditions when it comes to selecting an appropriate site for landfill in each area. The factors or criteria we used in this article are environmental, economic, and social criteria. In this research, the Geographic Information System (GIS) and the Analytical Hierarchy Process (AHP) were utilized to select the most suitable sites for landfill in Paveh, which the current landfill in this county does not follow environmental laws. In the process of zoning sites for landfill in Paveh, twelve various criteria were mapped and join for cover analyses within GIS application to construct the last suitability index map for the site. The weightings of criteria were done with the help of AHP, and the weightings of the criteria were identified based on various factors. For this purpose, we used expert's opinions, governmental regulations, and previous literature. Paveh is located in Kermanshah in the western part of Iran with $736 \mathrm{~km}^{2}$ area. The results show that almost $93 \%$ of the study areas is improper for landfill sitting.
\end{abstract}

Keywords: Landfill site; solid waste; AHP; GIS

Received: May 12, 2020, / Accepted: July 152020 / Online: July 252020

\section{INTRODUCTION}

One of the definitive environmental issues connected to Municipal Solid Wastes (MSW) is solid waste management that is the first interest to government and municipal funding and city managers. Municipal solid waste containing factors like bottles, cans, waste gardeners, food, product packaging, furniture, clothing, newspapers, batteries, institutions, commercial origins, and hospitals [1,2]. The problem of municipal solid waste in third world countries or developing countries is more serious because of poor planning, urban development, the absence of solid waste management practiced, and insufficient resources come up with poor conditions [3]. Developing countries often dump their MSW in open and inappropriate places that are not properly designed for this purpose, and along with burning it, they reduce a little volume of waste [3].

Proper management of MSW requires a well understanding of the quantity and quality of waste, the economic costs of operating and establishing a suitable location, and the environmental impact of this process [4]. Composting and recycling waste are the most usual ways for MSW management in the world [4,5]. The merge of these management methods is employed to manage MSW; however, the existence of a hygienic landfill could not be disregard in a Municipal Solid Wastes management system [6,7]. The hygienic landfill is an accepted technique for municipal wastes there for the building expense and plain process, and it is a necessary part of Municipal Solid Wastes systems [8,9].

Improper landfills have considerable environmental issues on the environment components like soil fertility, natural habitats, water resources and landscape sight $[10,11,12]$. To decrease the opposed impacts on the environment, it is essential to consider all environmental standards in selecting landfill sites. Further, economic and social items play a fundamental role in selecting landfill sites because of the commercial expense, just like the social protest $[13,14,15]$. The different environmental, economic and social factors make a complex operation in the selection of landfill sites, and it is hard to collect and analyze various parameters and perform the conclusion clearly [16,17].

The combination of the GIS and the AHP method is mainly employed to solve the problem of landfill sites. The GIS performance main character contributes to cover analysis for choosing a suitable landfill site since it has a high skill to consider different factors from a variety of sources and manage large volumes of spatial data [18,19,20]. GIS has a high capability to come to terms with the restrictions of fundamental environmental, economic, and other terms. [21]. GIS in the combination of multi-criteria analysis methods has widely been employed for landfill site 
selection different $[14,22,23,24,25]$ as well as other suitability proposes containing the estimation of soil environment [26], groundwater pollution potential [27], and energy site selection [28].

The aim of this article is to determine the most appropriate candidate sites for landfill in Paveh that satisfy the scientific criteria and environmental. For obtaining this aim, an important criterion that can influence the environment was considered by way of merging the AHP technique and GIS software. The process of selecting a landfill site includes steps: reviewing resource, browse instructions and use expert's opinion to identify evaluation criteria, then use GIS to prepare the require maps correspond with the desired criteria, appropriate weighting to each part of data, and combine this information together is cause the selection of the optimal locations.

\section{STUDY AREA}

Paveh is located in western Iran and is $112 \mathrm{~km}$ far from Kermanshah. It lies in a sub-region along the Iran-Iraq border, and the city position is located on the latitude of $35^{\circ} 02^{\prime} 36^{\prime \prime}$ North and longitude of $46^{\circ} 21^{\prime} 23^{\prime \prime}$ East; the case study area is $736 \mathrm{~km}^{2}$ which is 6 percent of Kermanshah province (Fig. 1). The total population of the study are at the 2017 census, its population was 25,771, in 7932 families www.amar.org.ir. Statistical Centre of Iran. Retrieved 4 February 2015). The weather condition of the region is semihumid, where average temperature and average annual rainfall have been recorded $15^{\circ} \mathrm{C}$ and $800 \mathrm{~mm}$. Changing lifestyle and economic development in the region has led to a considerable increase in population and generation of municipal solid wastes. The daily waste generation is nearly 40 tons per day. Wastes gather regularly by the municipality and drop them in an inappropriate way in an open area.

\section{MethodOLOGY}

To appraise the study area in choosing an appropriate site location for landfill, GIS and its specific analysis tools were employed to equip the map layers overlaying twelve criteria in the study area based on expert's opinions in this domain. The landfill siting model, relying on current criteria, can be divided into the following methods:

\section{Peruse the prior research.}

2. Making ready the database of digital maps in GIS application for the case study.

3. Making appropriate zones or specific limitations around significant areas with Euclidean distance to suit every criterion map.

4. definition of the weightings of the criteria according to expert's opinion, governmental regulations, environmental and literature.

5. definition of the weightings for the criteria utilizing the AHP model.

6. Educe inappropriate areas for landfill site location from the concluding final map of this article.
7. define the appropriate index for candidate locations for landfill and display them.

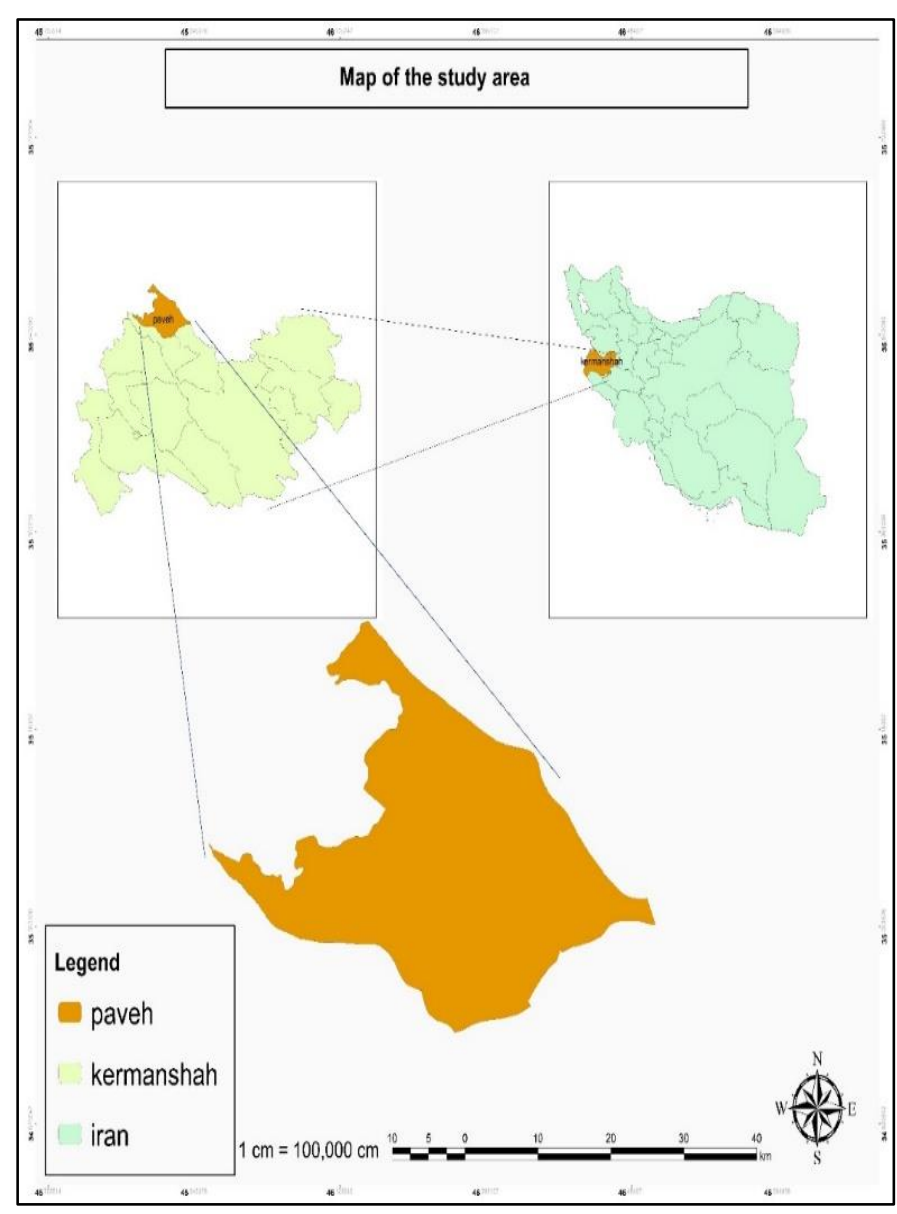

Fig.1. Study area

\subsection{The Hierarchical Structure Tree for Landfill Siting}

The first step of the methodology for this article includes making a hierarchy for decision problems. The goal of the decision problem was landfill site selection for Paveh. The hierarchical construction was constructed according to the opinions of experts and earlier studies with available data in the study area. In this case, twelve criteria were chosen and classified into the main group and were showed in fig.2. Group number one was environmental criteria that involve soil type, Distance from fault, Distance from the river, Landuse type, Rainfall, Wind direction, Distance from protected areas, Evaporation rate. Group number two was economic criteria included slope and distance from road sub-criteria, and group number three criteria was the social factor, which is included distance from residential areas and distance from religious areas. The data mostly obtained from satellite images, field surveys, 1:100,000 scale geological maps, 1:50,000 scale topographic maps and statistics, and available information from organizations. 


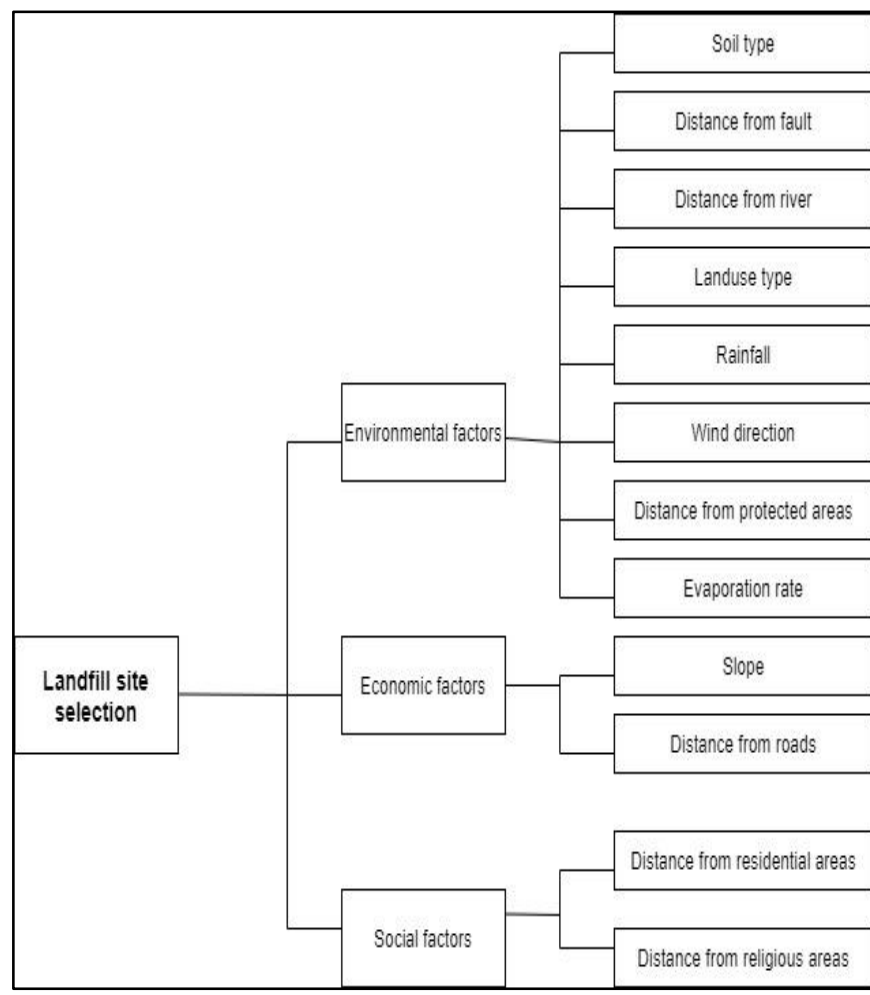

Fig.2 Hierarchical structure

In many projects which is performed in ArcGis are use different proximity functions. One of these functions is the Euclidean distance tool in ArcGiIS For example, in all articles and projects known as location or zoning in GIS Definitely, one of the criteria or effective variables is the distance map to a certain point. For example:

Map based on distance from main roads

Map based on distance from residential areas

Map based on distance from fault, etc...

All of these criteria are maps based on a linear, point, or polygon map. The maps based on distance will be in the form of raster maps that the distance of each pixel in the map actually represents the shortest distance to the criterion which This distance is calculated as the horizontal distance. with this algorithm there are maps of criteria (Fig3, Fig4, Fig5).

\subsection{Weighting criteria}

The weight of criteria is concluded to explain the significance of the criteria. To conclude the weight of parameters that have different significance, AHP, an effective method introduced by Saaty was employed. The weight of factors is defined by 3 stages in the AHP method.

1) The decision-making problem is divided into two levels involving criteria and sub-criteria. They are shown with details in fig2.

2) The appropriate weight by using previous comparisons (reviewing sources) and using expert's opinions evaluated from 1 to 9 (show in Table 1). All comments are entered by using geometric integration in Expert Choice, and the final weight of each criterion was achieved. The weight of each criterion is between 0 and 1 , and the sum of these weights is equal to 1 [29]. The result of weighting is displayed in Table2.

3) the final landfill suitability map by overlaying the standardized maps is produced. The Weighted Linear Combination (WLC) technique is used to accumulate the maps in this article. Since WLC is simple and easy to implement with the GIS environment we use it, it is the most common method in multi-attribute decision analysis. The equation of WLC technique is as follows:

$\mathrm{S}=\sum \mathrm{Wi} * \mathrm{Xi}$

which Wi is layer's normalized weight, $\mathrm{Xi}$ is standardized raster layers and $\mathrm{S}$ exhibit the final map. 
Rostampoor et al. / Journal of Civil Engineering Frontiers Vol. 01, No. 01, pp. 07 -15, (2020)

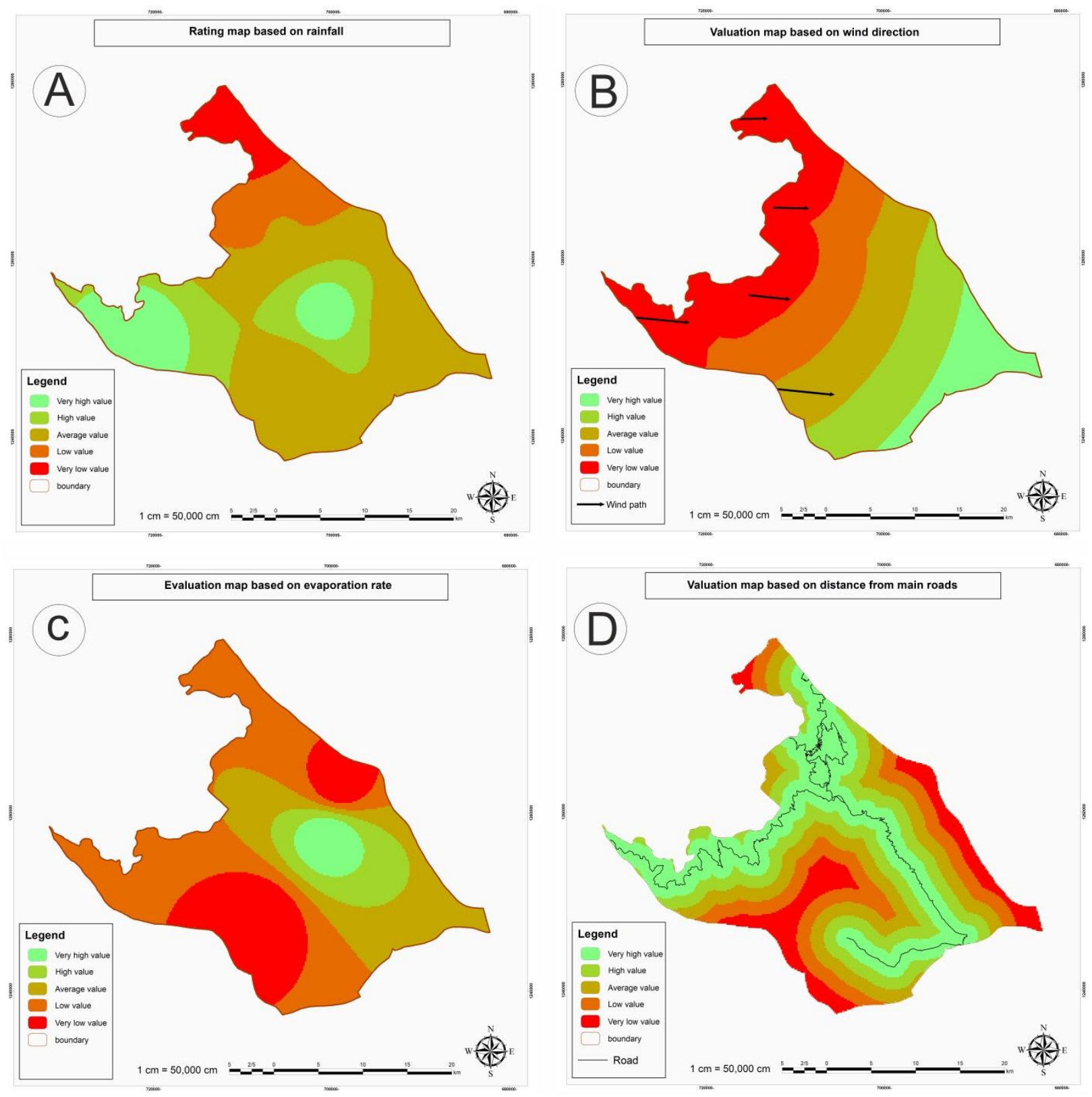

Fig. 3: A: rating map based on rainfall B: valuation map based on wind direction; C: valuation map based on evaporation rate; D: valuation map based on distance from main road 
Rostampoor et al. / Journal of Civil Engineering Frontiers Vol. 01, No. 01, pp. 07 -15, (2020)

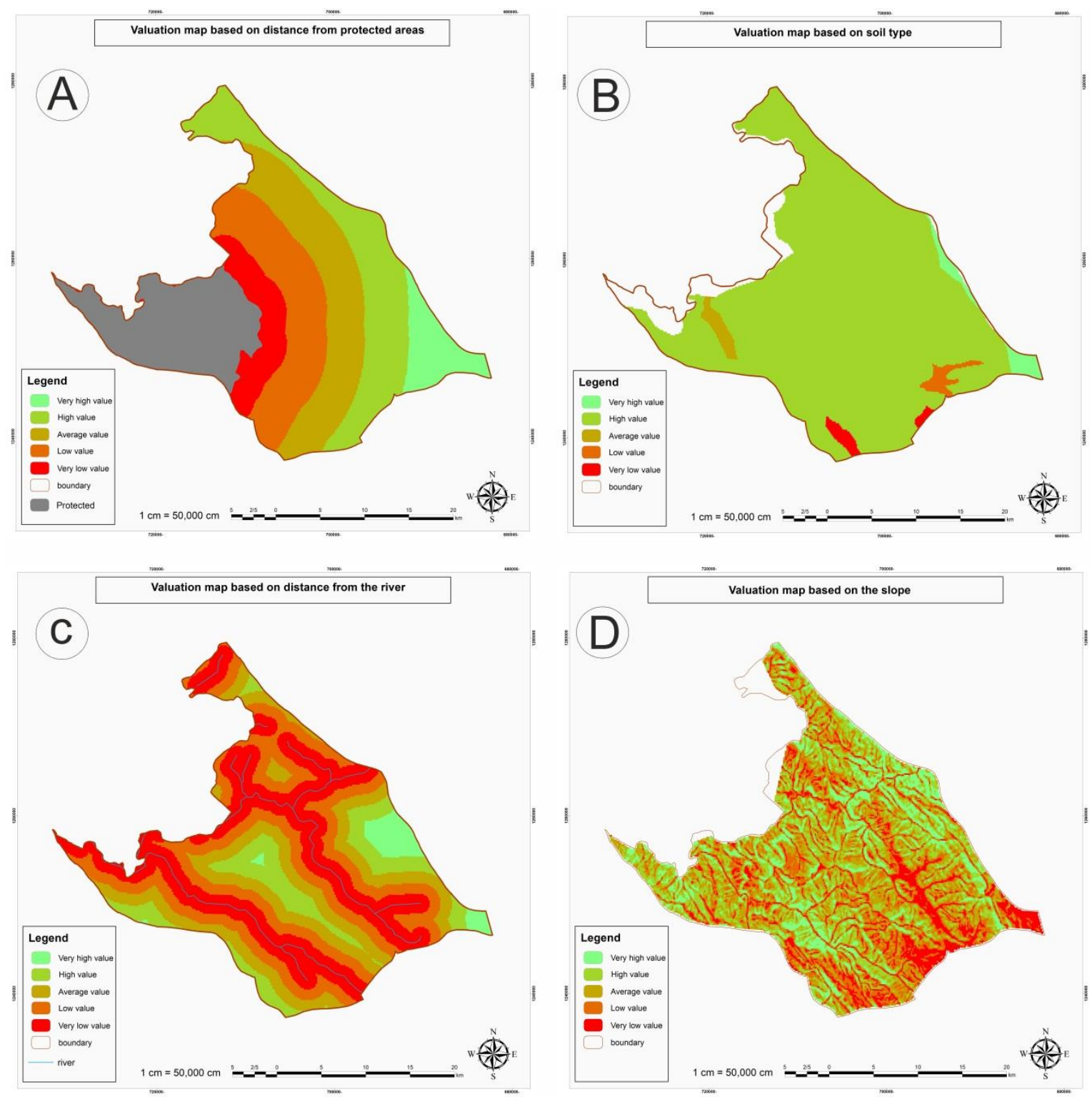

Fig. 4: A: valuation map based on distance from protected areas; B: valuation map based on soil type; C: valuation map based on distance from the river; D: valuation map based on distance from the slope 
Rostampoor et al. / Journal of Civil Engineering Frontiers Vol. 01, No. 01, pp. 07 -15, (2020)

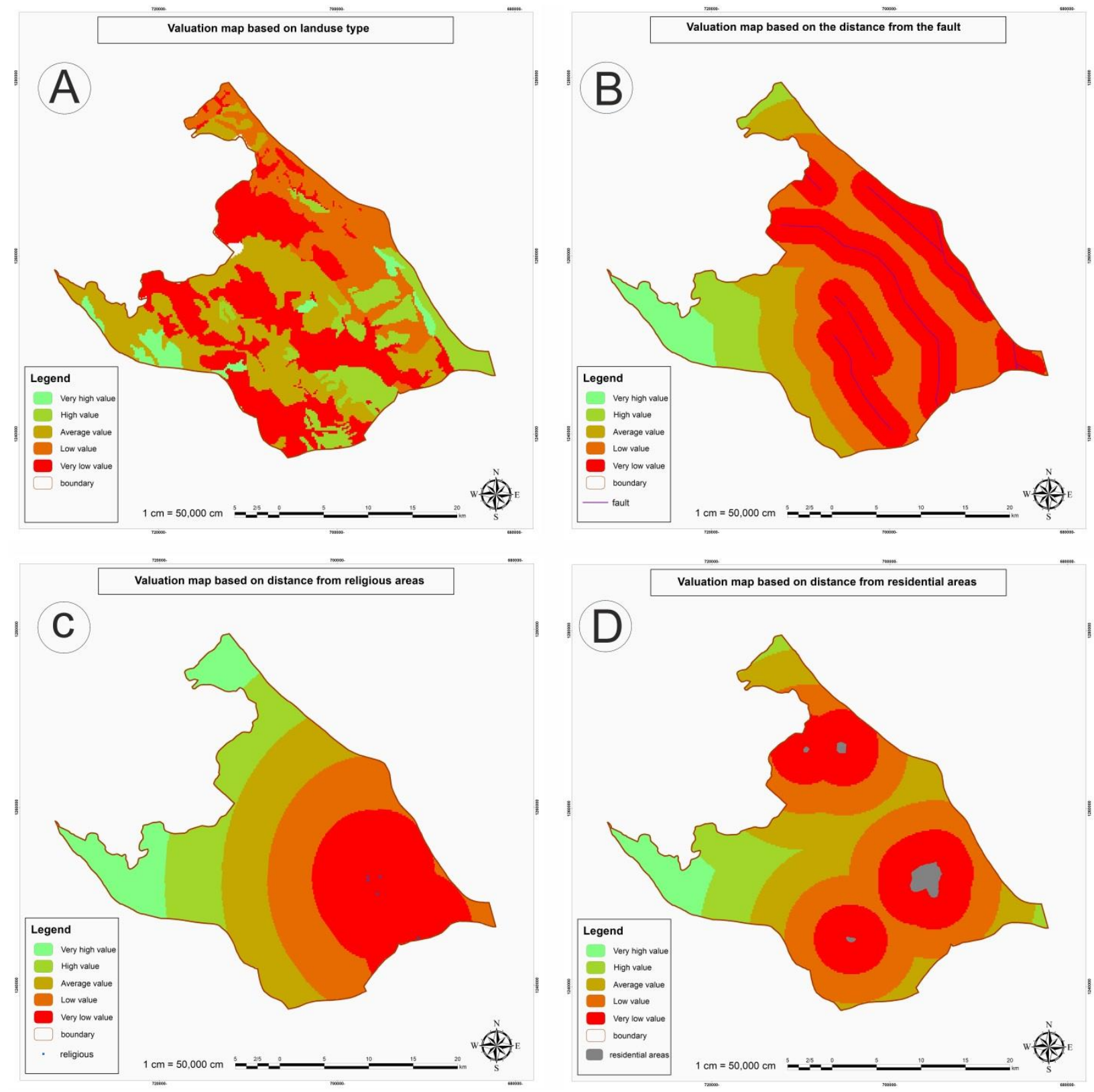

Fig. 5. A: valuation map based on landuse type; B: valuation map based on distance from the fault; C: valuation map based on distance from religious areas; D: valuation map based on distance from residential areas 
TABLE I. SAATY AND VARGAS PREFERENCES SCALES

\begin{tabular}{|c|c|c|}
\hline \multicolumn{2}{|c|}{ Intensity of importance } & Description \\
\hline & & Equal importance \\
\hline 2 & & Equal to average importance \\
\hline 3 & & Average importance \\
\hline 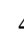 & & Average to strong importance \\
\hline 5 & & Strong importance \\
\hline 6 & & Strong to very strong importance \\
\hline r & & Very strong importance \\
\hline 8 & Very & y strong or super strong importance \\
\hline 9 & & Super strong importance \\
\hline
\end{tabular}

TABLE II. THE WEIGHTING OF THE CRITERIA USING AHP METHOD

\begin{tabular}{lc} 
Parameters & Weight \\
\hline Soil type & 0.248 \\
Distance from fault & 0.206 \\
Distance from river & 0.130 \\
Land use & 0.091 \\
Rainfall & 0.059 \\
Wind direction & 0.040 \\
Distance from protected areas & 0.029 \\
Evaporation rate & 0.014 \\
Slope & 0.081 \\
Distance from road & 0.018 \\
Distance from residential & 0.056 \\
Distance from religious areas & 0.022
\end{tabular}

\section{RESULTS AND DISCUSSION}

The first purpose of this study is to suitable zoning areas for optimal landfilling of municipal waste. For this purpose, the first 3 criteria: environmental, economic, and social criteria and 12 sub-criteria: soil type, distance from the fault, distance from water river, precipitation(rainfall), prevailing wind direction, distance from protected areas, evaporation, slope, distance from the road, distance from residential areas and distances from religious areas were selected. These criteria and subcriteria were prepared by studying similar works and by examining the desired area and the opinion of experts. Then the information layers of every sub-criteria and the information tables of each sub-criteria were sorted and finally turned into raster maps.

Using the hierarchical analysis method, the weight of the layers must first be obtained; For this purpose, using the Delphi method and the opinion of expert's in various fields, the criteria were weighted and using the AHP method and software (Expert choise11), the final weight of the layers was calculated with an incompatibility coefficient of 0.05 , in which the distance layers from the fault and Soil material had the highest weight.

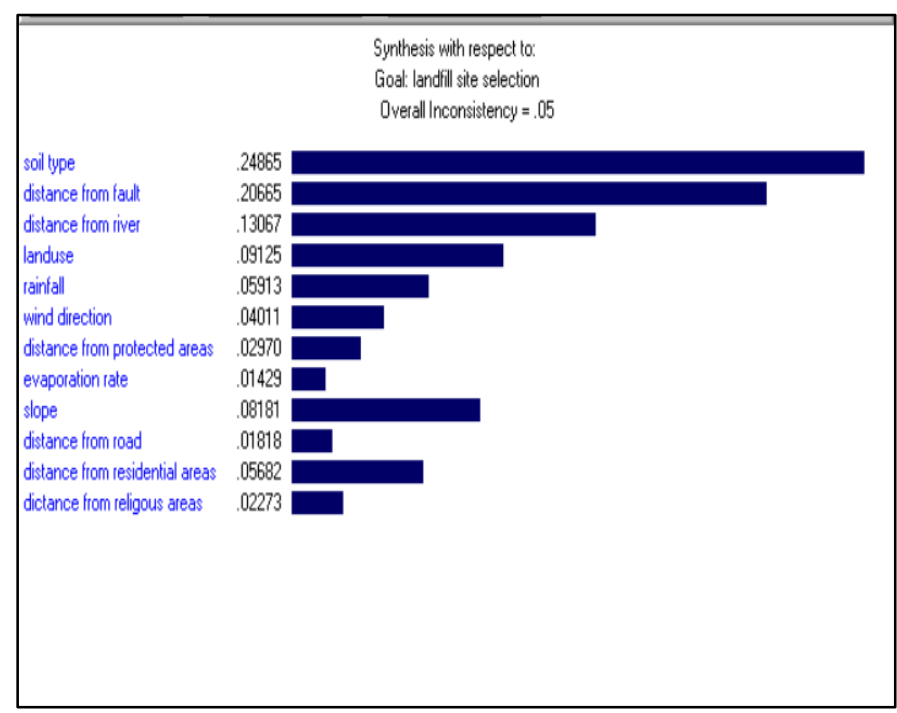

Fig. 6. Weighting on expert choice

AHP method and finally, with the help of ArcGIS software, the categories: very high value, High value, Average value, very low value, Low value.The results show that $24 \%$ of the study area has very poor landfill (red), $27 \%$ has poor landfill (orange), 26\% has medium landfill (yellow), 16\% has good landfill (light green), and $7 \%$ has a very high capacity (dark green) for landfilling. According to Fig. (4), the most proper area for landfill is located in the eastern part of the province; Because this area has a good distance from access roads, urban and rural areas, rivers, and residential areas.

TABLE II: SUITABILITY CLASSES

\begin{tabular}{|l|l|l|}
\hline \multicolumn{1}{|c|}{ Suitability class } & \multicolumn{1}{|c|}{ Area(km2) } & Area(\%) \\
\hline Very high value & 51.68794 & 7 \\
\hline High value & 120.257577 & 16 \\
\hline Average value & 187.556744 & 26 \\
\hline Low value & 203.941258 & 27 \\
\hline Very low value & 173.3111262 & 24 \\
\hline Sum & 736.7546452 & 100 \\
\hline
\end{tabular}




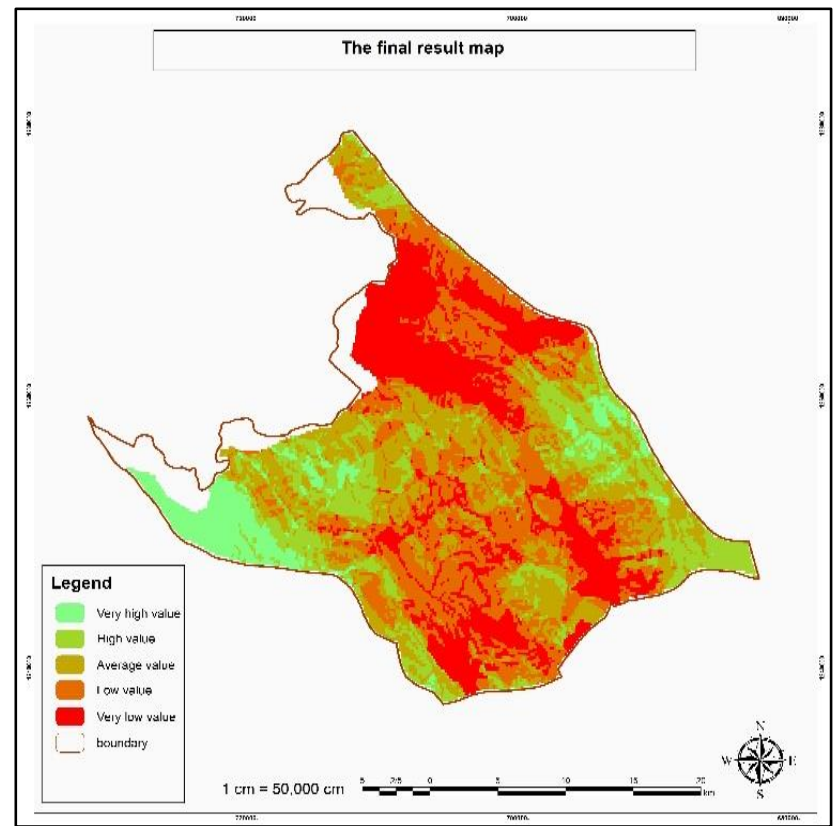

Fig. 7.Final map of landfill suitability

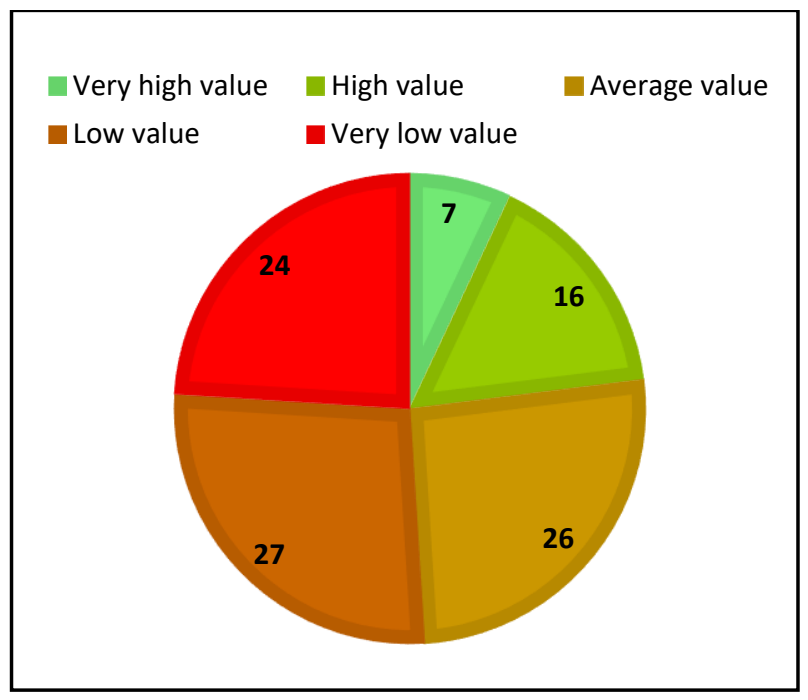

Fig. 8. exhibition values with percentages

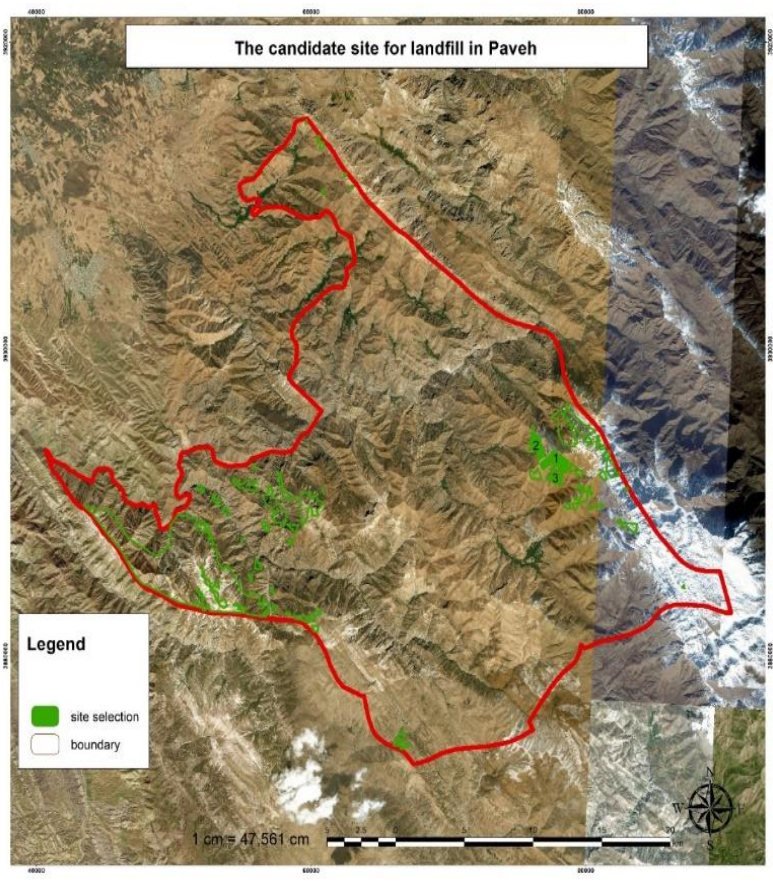

Fig. 9. Final landfill suitability map

\section{CONCLUSION}

Increasing waste in Paveh county and its lack of proper management and disposal of waste in the surrounding environment, requires further studies to build an optimized and engineered landfill that has the least environmental damage, and has the lowest cost and in terms of Social also creates the least social protests.

In this study, using GIS and AHP techniques, suitable locations for optimal landfilling was selected. GIS is a powerful tool that can provide fast and accurate evaluation and has a high ability to manage large volumes of data from various sources; AHP, on the other hand, is a powerful way to solve complex problems. The integration of GIS and AHP methods provides decision-makers with an accurate and immediate review at the lowest cost.

In this article, 12 criteria were studied, then the required information layers were prepared and standardized; Then, the desired layers were weighted by the AHP method, and finally, with the help of ArcGIS software, these weighted information layers were combined, and finally 5 classes are shown in the final map.(Very high value، High value‘Average value، Low value، Very low value). The present study showed that very suitable landfills for the waste of Paveh county cover an area of 51.68794 or about $7 \%$ of the total classified sites; Which are mainly located in the eastern half of the county. For landfill siting in Paveh, three candidate locations were selected. The area of site No.1 was $1.356 \mathrm{~km}^{2}$, the area of site No.2 was $1.019 \mathrm{~km}^{2}$ and the area of No.3 was $0.633 \mathrm{~km}^{2}$.

\section{REFERENCES}

[1] EPA (U.S. Environmental Protection Agency) (2016) Municipal solid waste. https ://www.epa.gov/repor t-environment 
[2] Pichtel J (2005) Waste management practice. Taylor \& Francis Group, Boca Raton

[3] Ferronato N, Torretta V, Ragazzi M, Rada EC (2017) Waste mismanagement in developing countries: a case study of environmental contamination. UPB Sci Bull Ser D 79:185-3

[4] Chandrappa R, Brown J (2012) Solid waste management. Springer, Berlin. https ://doi.org/10.1007/978-3-642-28681 -0

[5] Ludwig C, Hellweg S, Stucki S (2003) Municipal solid waste management. Springer, Berlin. https ://doi.org/10.1007/978-3-64255636-4

[6] Kharlamova MD, Mada SY, Grachev VA (2016) Landfills: Problems, Solutions, and Decision Making of Waste Disposal In Harare (Zimbabwe). Biosci Biotech Res Asia 13(1)

[7] Santhosh LG, Sivakumar BG (2018) Landfill site selection based on reliability concepts using the DRASTIC method and AHP integrated with GIS - a case study of Bengaluru city, India. Georisk Assess Manag Risk Eng Syst Geohazards 12(3):234-252. https :// doi.org/10.1080/17499 518.2018.14345 48pp. 271-350.

[8] Khorram A, Yousefi M, Alavi SA, Farsi J (2015) Convenient landfill site selection by using fuzzy logic and geographic information systems: a case study in Bardaskan, East of Iran. Health Scope 4(1):e19383K. Elissa, "Title of paper if known," unpublished.

[9] Rahmat ZG, Niri MV, Alavi N et al (2017) Landfill site selection using GIS and AHP: a case study: Behbahan, Iran. KSCE J Civ Eng 21:111118. https ://doi.org/10.1007/s1220 5-016-0296-9

[10] Al-Anbari MA, Al-Ansari N, Jasim HK (2014) GIS and multi-criteria decision analysis for landfill site selection in Al-Hashemiyah Qadaa. Nat Sci 6:282-304. https ://doi.org/10.4236/ns.2014.65032

[11] Feo GD, Gisi SD (2014) Using MCDA and GIS for hazardous waste landfill siting considering land scarcity for waste disposal. Waste Manag 34(11):2225-2238. https ://doi.org/10.1016/j.wasma n.2014.05.028

[12] Kapilan S, Elangovan K (2018) Potential landfill site selection for solid waste disposal using GIS and multi-criteria decision analysis (MCDA). J Cent South Univ 25(3):570-585

[13] Eskandari M, Homaee M, Mahmodi S (2012) An integrated multi criteria approach for landfill siting in a conflicting environmental, economic and socio-cultural area. Waste Manag 32(8):1528-1538. https ://doi.org/10.1016/j.wasma n.2012.03.014

[14] Karimi, H., Amiri, S., Huang, J. et al. Integrating GIS and multi-criteria decision analysis for landfill site selection, case study: Javanrood County in Iran. Int. J. Environ. Sci. Technol. 16, 7305-7318. https://doi.org/10.1007/s13762-018-2151-7

[15] Santhosh LG, Sivakumar BG (2018) Landfill site selection based on reliability concepts using the DRASTIC method and AHP integrated with GIS - a case study of Bengaluru city, India. Georisk Assess Manag Risk Eng Syst Geohazards 12(3):234-252. https :// doi.org/10.1080/17499 518.2018.14345 48

[16] Khan MH, Vaezi M, Kuma A (2018) Optimal siting of solid waste tovalue-added facilities through a GIS-based assessment. Sci Total Environ 610:1065-1075. https ://doi.org/10.1016/j.scitotenv.2017.08.169

[17] Karimzadeh Motlagh Z, Sayadi M (2015) Siting MSW landfills using MCE methodology in GIS environment (Case study: Birjand plain, Iran). Waste Manag 46:322-337. https ://doi.org/10.1016/j. wasma n.2015.08.013

[18] Barakat A, Hilali A, Baghdadi M, Touhami F (2016) Landfill site selection with GIS-based multi-criteria evaluation technique A case study in Béni Mellal-Khouribga Region, Morocco. Environ Earth Sci 76:413. https ://doi.org/10.1007/s1266 5-017-6757-8

[19] Kontos, T.D.; Komilis, D.P.; Halvadakis, C.P. Siting MSW landfills on Lesvos Island with a GIS based methodology. Waste Manag. Res. 2003, 21, 262-277. [CrossRef] [PubMed]
[20] El Alfy, Z.; Elhadary, R.; Elashry, A. Integrating GIS and MCDM to Deal with landfill site selection. Int. J. Eng. Technol. 2010, 10, 32-42.

[21] Karimi H, Herki B, Gardi S, Galali S, Hooshyar Hossini, Karamreza Mirzaei \& Meghdad Pirsaheb (2020) Site selection and environmental risks assessment of medical solid waste landfill for the City of Kermanshah-Iran, International Journal of Environmental Health Research, DOI: 10.1080/09603123.2020.1742876

[22] Nas, B.; Cay, T.; Iscan, F.; Berktay, A. Selection of MSW landfill site for Konya, Turkey using GIS and multi-criteria evaluation. Environ. Monit. Assess. 2010, 160, 491-500. [CrossRef] [PubMed]

[23] Aksaler, N.; Yerli, S.K.; Erdogan, M.A.; Kaba, K.; Ak, T.; Aslan, Z.; Bakis, V.; Demircan, O.; Evren, S.; Keskin, V.; et al. Astronomical site selection for Turkey using GIS techniques. Exp. Astron. 2015, 39, 547566. [CrossRef]

[24] Zhu, B.; Nie, Y.; Nan, R.; Peng, B. The FAST/SKA site selection in Guizhou province. Sources Scintill. 2001, 278, 213-218.

[25] Saaty, T.L. The Analytic Hierarchy Process; McGraw Hill: New York, NY, USA, 1980.

[26] Saaty, T.L. Fundamentals of Decision Making and Priority Theory with AHP; RWS Publications: Pittsburg, PA, USA, 2000.

[27] Karimi H, Soffianian A, Seifi S, Pourmanafi S \& Ramin H (2020) Evaluating optimal sites for combined-cycle power plants using GIS: comparison of two aggregation methods in Iran, International Journal of Sustainable Energy, 39:2, 101112, DOI: $10.1080 / 14786451.2019 .1659271$

[28] Rahman, A. GIS based DRASTIC model for assessing groundwater vulnerability in shallow aquifer in Aligarh, India. Appl. Geogr. 2008, 28, 32-53. [CrossRef]

[29] Vahidnia, M.H.; Alesheikh, A.A.; Alimohammadi, A. Hospital site selection using fuzzy AHP and its derivatives. J. Environ. Manag. 2009, 90, 3048-3056. [CrossRef] [PubMed]

[30] Malczewski J (2004) GIS-based land-use suitability analysis: a critical overview. Prog Plan 62(1):3-65. ://doi.org/10.1016/j.progress.2003.09.002

[31] Karimi, H., S. Amiri, J. Huang, and A. Karimi. "Integrating GIS and multi-criteria decision analysis for landfill site selection, case study: Javanrood County in Iran." International Journal of Environmental Science and Technology 16, no. 11 (2019): 7305-7318.

[32] Chabuk, Ali, Nadhir Al-Ansari, Hussain Musa Hussain, Sven Knutsson, Roland Pusch, and Jan Laue. "Combining GIS applications and method of multi-criteria decision-making (AHP) for landfill siting in AlHashimiyah Qadhaa, Babylon, Iraq." Sustainability 9, no. 11 (2017): 1932.

[33] Al-Anbari, Mohammad A., Mohanad Y. Thameer, and Nadhir AlAnsari. "Landfill site selection by weighted overlay technique: case study of Al-Kufa, Iraq." Sustainability 10, no. 4 (2018): 999

[34] Shorabeh, Saman Nadizadeh, Ahmadreza Varnaseri, Mohammad Karimi Firozjaei, Fatemeh Nickravesh, and Najmeh Neysani Samany. "Spatial modeling of areas suitable for public libraries construction by integration of GIS and multi-attribute decision making: Case study Tehran, Iran." Library \& Information Science Research (2020): 101017.

[35] Şener, Şehnaz, Erhan Şener, Bilgehan Nas, and Remzi Karagüzel. "Combining AHP with GIS for landfill site selection: a case study in the Lake Beyşehir catchment area (Konya, Turkey)." Waste management 30, no. 11 (2010): 2037-2046. 